\title{
COFFEE IN AGRO-FORESTRY SYSTEMS INVOLVING DIFFERENT TREE SPECIES
}

\author{
J B Palipane. \\ Department of Export Agriculture \\ Nillambe.
}

The experiment was conducted to study the growth and yicld of arabica and robusta coflee grown in agro-foresry systems involving different shade tree species. The final objective is 10 select the best tree species as shade for coffec.

The experiment was conducted at Delpitiya in the mid country wet zone of Sri Lanka. The experiment site contained four tree species established in 1986 at $2.5 \mathrm{~m}$ x $2.5 \mathrm{~m}$ spacing. The four tree species were Gliricidia sepium. Calliandra calothyrsus, Acasia magnum and Eryhrind lithospermo. Robusla colfec in $2.5 \mathrm{~m} \times 2.5 \mathrm{~m}$ and arabica coffec in $1.25 \mathrm{~m} \mathrm{x}$ $1.25 \mathrm{~m}$ spacing were planted between the shade trees. The measurements were also made in a control treatment which had coffce without shade. Each treatment had three replicates.

Yield data of this experiment showed that the highest coffee yield was obtained under Gliricidia and Calliandra, next under Acacia and then Erythrina. The lowest yicld was obtained from coffee grown without shade.

Cotfee plants were collar pruned in 1996 and collected growih measurement of coffec showed signilicantly highest shoot growth under Gliricidia, Calliandra, Acacia and Eryhrima. Unhealthy stunted shoots were observed in the coffee grown without shade. Hence, it cin be concluded that coffee is best grown under Gliricidia, Calliandra, Acacia alid Erythrind shade. 